\title{
STATISTICAL ANALYSIS FOR IMPACTS OF ECONOMICAL CONDITIONS ON HOUSING MARKETS: AN EXAMPLE ON FRAGILE 5 COUNTRIES
}

DOI: 10.17261/Pressacademia.201519884

\author{
Ali HEPSEN ${ }^{1}$, Olgun AYDIN ${ }^{2}$, Orhan VATANDAS ${ }^{3}$ \\ ${ }^{1}$ Istanbul University, Turkey \\ ${ }^{2}$ Mimar Sinan University, Turkey \\ ${ }^{3}$ REIDIN, Turkey
}

\section{Keywords:}

Fragile five countries;

Housing market;

Macroeconomic indicators;

Krigingmetamodelling

\section{JEL Classification:}

E30, E44, L74, R10, R20, R30

\begin{abstract}
In the year 2013, Morgan Stanley declared the Brazilian real, the Indian rupee, the Indonesian rupiah, the South African rand and the Turkish lira as the "Fragile Five," or the troubled emerging market currencies under the most pressure against the U.S. dollar. For those countries, housing market has been a key driver of growth and has been a steady and robust performer since the year 2000 . The main purpose of this study is to investigate, modeling whether there is a long-run relationship between macroeconomic indicators and housing markets in Fragile Five countries by correlation analysis, regression, krigingmetamodelling for the twelve year period from 2002 to 2013. The findings of this paper would help government and property investors for creating more effective property management strategies in these countries.
\end{abstract}

\section{INTRODUCTION}

An emerging market is a country that has some characteristics of a developed market but is not yet a developed market. This includes countries that may be developed markets in the future or were in the past. It may be a nation with social or business activity in the process of rapid growth and industrialization. The four largest emerging and developing economies by gross domestic product (GDP) are the BRIC countries (Brazil, Russia, India and China); the next four largest markets are MIKT (Mexico, Indonesia, South Korea and Turkey) and finally there is a new terminology named Fragile 5 (Brazil, India, Indonesia, Turkey and South Africa) in the emerging market.

According to the International Monetary Fund (IMF), there are 25 countries classified as emerging market economies. They exhibit varying levels of economic growth, inflation, trade and fiscal conditions. Ten years ago, Goldman Sachs declared Brazil, Russia, India and China (BRIC) as the emerging markets with the brightest economic growth prospects. 
In the year 2013, Morgan Stanley declared the Brazilian real, the Indian rupee, the Indonesian rupiah, the South African rand and the Turkish lira as the "Fragile Five," or the troubled emerging market currencies under the most pressure against the U.S. dollar. According to Morgan Stanley's report these countries have important things in commonhigh inflation, weakening growth, large external, and high dependence on fixed income inflows leave these currencies vulnerable. The risks associated with these particular five currencies are also evident from the fact that central banks in these countries have been among the most aggressive in their bid to support their currencies.

The main purpose of this study is to investigate, modelling whether there is a long-run relationship between macroeconomic indicators and housing markets in Fragile 5 countries by impulse/ response analysis, variance decomposition, correlation analysis, regression, krigingmetamodelling for the twelve year period from 2002 to 2013.

The following section provides overview of fragile five countries and selected macroeconomic parameters. Section five and six explain the theoretical framework adopted in this study and the results. The final section is the conclusion.

\section{LITERATURE REVIEW}

Ghysels (2012) studied the evidence of predictability in US residential and commercial real estate markets. First, they highlight the main methodologies used in the construction of real estate indices, their underlying assumptions and their impact on the stochastic properties of the resultant series. Then survey the key empirical findings in the academic literature, including short-run persistence and long-run reversals in the log changes of real estate prices. Next, they summarize the ability of local as well as aggregate variables to forecast real estate returns. They illustrate a number of these results by relying on six aggregate indexes of the prices of unsecuritized (residential and commercial) real estate and REITs. The effect of leverage and monetary policy is also discussed.

Seth (2011) examined residential investments signals an impending decline in economic activity. Sources of demand for both residential and commercial real estate sectors are similar and this should move the markets in the same direction over the long-run. Since the residential market has already collapsed, the study of real estate investments is important. This paper utilizes real estate and macroeconomic data to forecast investment loans. Cointegration methods are used for the forecast because the data displays a tendency to move together. The results show that the forecast is inconsistent with the positive relationship between both real estate markets; the residential market will continue to decline, whereas the commercial market with see a positive growth from 2011-2012.

Guo (2012) analyzed monthly averaged prices of commercial residential building in Changsha City from Jan, 2002 to Dec, 2011, this paper construct a forecasting model to predict short-term housing price trend and affords reference to homebuyer and investors, what's more, affords technical support to government's policy making. Selected rational forecasting model is discussed, and then a price forecasting ARMA model is constructed. 
Emara (2014) examined the impact of liberal policies on the economic performance of labor and capital productivity in the Middle East and North African (MENA) countries, by using nonlinear panel least squares regression with regional dummies and period fixed effects (LSDV) for a sample of 18 MENA countries over the period 1995-2009. He estimated the impact of different aspects of economic freedom on labor and capital productivity. Saljoughian et al. (2013) evaluated the performance of OECD countries and identified the most critical science and technology factors in these countries by using the indicators of science and technology progress suggested by World Bank and exploiting Data Envelopment Analysis (DEA). They measured the efficiency of these countries. They ranked the countries and performed the sensitivity analyses of the factors by Norm-2 method in order to identify the most important factors.

Öztürk, Sözdemir and Ülger (2013) examined growth rates (GDP) in developed and developing countries that is implement of inflation targeting strategy show how a change in the period before and after the crisis (2005-2011). They took into account the inflation performance of those countries for the same period. They compared growth and inflation performances of the countries by means of table and graphical form.

\section{SELECTED MACROECONOMIC PARAMETERS AND FRAGILE FIVE COUNTRIES}

\subsection{Selected Macroeconomic Parameters}

Our paper comprises dependent and independent variables: while dependent variable of analyze is residential property price index (RPPI); the independent variables are gross domestic product, current account balance, general government gross debt, general government revenue, gross national savings, inflation (average consumer prices), population, total investment, unemployment rate, real interest rate, volume of exports of goods and services, volume of imports of goods and services. The objective of the residential property price index (RPPI) is to provide an accurate measure of the contemporary rate of change in the prices of the properties. There are a lot of individuals or organizations use residential property prices indices directly or indirectly either to influence practical decision making and conduct of economic policy. Analysts, policymakers, investors and financial institutions follow trends in house prices to expand their understanding of real estate and credit market conditions as well as their impact on economic activity, and financial stability and soundness. For instance, mortgage lenders use this information to gauge default risk and central banks often rely on movements' in house price indices to track households borrowing capacity and aggregate consumption.

Gross Domestic Product represents the economic health of a country. It presents a sum of a country's production which consists of all purchases of goods and services produced by a country and services used by individuals, firms, foreigners and the governing bodies. GDP consists of consumer spending, investment expenditure, government spending and net exports hence it portrays an all-inclusive picture of an economy because of which it provides an insight to investors which highlights the trend of the economy by comparing GDP levels as an index. GDP is not only used as an indicator for most governments and economic decision-makers for planning and policy formulation; but also it helps the investors to manage their portfolios by providing them with guidance about the state of the

economy. 
On the other hand, it is good measure for an economy and with improvement in research and quality of data, statisticians and governments are trying to find out measures to strengthen GDP and make it a comprehensive indicator of national income. International standards regarding the compilation of balance of payments statistics are described in the fifth edition of the Balance of Payments Manual prepared by the International Monetary Fund (IMF) in order to provide guidance to member countries. In a general sense, the balance of payments is a statistical statement that systematically records all the economic transactions between residents of a country (Central Government, monetary authority, banks, other sector) and nonresidents for a specific time period. The balance of payments statistics are classified under two major groups: "Current Account" and "Capital and Financial Account". In summary, the current account covers all transactions that involve real sources (including volume of exports and imports of goods and services,) and current transfers; the capital and financial accounts show how these transactions are financed (by means of capital transfer or investment in financial instruments). As mentioned in the European Economic series, current account deficits and surpluses are not necessarily macroeconomic imbalances in the sense of developments which are adversely affecting, or have the potential to affect the proper functioning of economies, of the monetary union, or on a wider scale. Deficits and surpluses are a natural consequence of economic interactions between countries. They show to which extent a country relies on borrowing from the rest of the world or how much of its resources it lends abroad. In this way, external borrowing and lending allows countries to trade consumption over time: a country with a current account surplus transfers consumption from today to tomorrow by investing abroad. In turn, a country with a current account deficit can increase its consumption or investment today but must transfer future income abroad to redeem its external debt. Deficits and surpluses can thus simply be the result of an appropriate allocation of savings, taking into account different investment opportunities across countries. Differences in economic prospects lead to differences in saving behavior, with brighter expectations reducing the tendency of economic agents to save and hence contributing to the accumulation of deficits. In particular, countries with a rapidly ageing population may find it opportune to save today (i.e. run surpluses) to smooth consumption over time. On the other hand, current account deficits and surpluses are part of the adjustment process in a monetary union. They absorb asymmetric shocks in the absence of independent monetary policy and nominal exchange rate adjustment. In determining the economic position of a country is through a comparison of general government gross debt, revenue, total expenditure, national savings and total investments to the gross domestic product of the country. For instance, a low government gross debt to GDP percentage is usually an indication of economic health, while a high debt to GDP percentage can indicate financial trouble for a country.

This paper also attempts to analyze the correlation that exists between RPPI and inflation plus real interest rates. Inflation refers the rate at which the general level of prices for goods and services is rising, and, subsequently, purchasing power is falling. On the other hand, the real interest rate is the rate of interest an investor expects to receive after allowing for inflation. It can be described more formally by the Fisher equation, which states that the real interest rate is approximately the nominal interest rate minus the inflation rate. 


\subsection{Brief Information For Fragile Five Countries}

As mentioned, Morgan Stanley declared Brazil, India, Indonesia, South Africa and Turkey as the "Fragile Five" countries in the year 2013 due to their vulnerable economies. The first country among them is Brazil. Brazil is recovering gradually from the growth slowdown that started in mid-2011, but the recovery remains uneven and inflation elevated.

Output is estimated at potential with supply-side constraints, linked to tight labor market conditions and protracted weak investment since 2011, limiting near term growth. Excessive fine tuning of fiscal policy (including through public banks) has weakened the credibility of Brazil's long-standing fiscal framework, while broader policy uncertainty has weighed on investment. On the other hand, global financial conditions and commodity prices may directly affect Brazilian GDP growth rate for the following years (IMF Brazil Country Report 2013).

The tightening of global liquidity has increased external pressures and heightened the focus on India's macroeconomic imbalances (high inflation, large current account and fiscal deficits) and structural weaknesses (particularly supply bottlenecks in infrastructure, power and mining). Growth is expected to slow to $5.4 \%$ in the year 2014, reflecting global developments and domestic supply constraints. The current account deficit is narrowing, driven by a significant improvement in exports, robust remittances flows, and a rapid diminution of gold imports. High and persistent inflation is a key macroeconomic challenge facing India. If external pressures from global financial market volatility resume, Indian rupee flexibility should be the first line of defense, complimented by use of reserves, increases in short-term interest rates, actions on the fiscal front, and further easing of constraints on capital inflows (IMF, India Country Report 2013).

A slowdown in growth in major emerging market economies (EMEs) and decline in commodity prices, and more recently, a reversal in push factors tied to a prospective exit from extraordinarily easy global monetary conditions, has put pressure on Indonesia's balance of payments and heightened its vulnerability to shocks. Domestic policy accommodation and rising energy subsidies have also given rise to increased external and fiscal imbalances. Recent policy tightening, fuel price hikes, and exchange rate flexibility have been firmly aimed at reducing these pressures. Growth is projected to slow to $5.36 \%$ in 2014. Inflation will likely peak at just below $10 \%$ at end 2014 , due mainly to the one-off effect of June 2013 fuel price increases and rupiah depreciation. The current account deficit is expected to exceed 3 percent of GDP in 2014 on weak commodity exports. Reserves have also come under pressure, partly due to Bank Indonesia's heavy intervention in the foreign exchange market in mid-2013. Recent market volatility and reserve losses highlight the need to deal decisively with macroeconomic imbalances and contain financial stability risks (IMF Indonesia Country Report 2013).

South Africa has made impressive strides in economic development over the past two decades. But in recent years, lower growth has exacerbated high unemployment, inequality, and vulnerabilities. Although weak trading partner growth contributed, domestic factors were an important reason why South Africa's growth has been below that of other emerging markets. 
Large current account and fiscal deficits, so far easily financed by global liquidity, have raised vulnerabilities (IMF, South Africa Country Report 2013).

Finally, Turkey has a stronger domestic demand, with the current account deficit is widening again from a high level, and inflation remains well above target (7.6\%). Increasing national savings and improving competitiveness are central to addressing vulnerabilities. On the other hand, economic growth lost momentum in the course of 2013, as capital market tensions pushed interest rates up. Credit and private demand decelerated. Export growth fell, notably due to rapidly declining gold sales. Political tensions have dented confidence, provoking capital outflows and forcing the central bank to raise interest rates sharply in early 2014. Growth is projected to remain subdued through mid-2015, while the current account deficit will remain very high. Sustaining domestic and international confidence is crucial. Monetary, fiscal and financial policies should remain prudent. Improving fiscal transparency with timely general government accounts and comprehensive reporting on the activities of quasi-fiscal institutions is recommended. Disinflation is essential to preserve the bulk of recent competitiveness gains and to allow Turkey to benefit more from the projected recovery in global trade. Increasing the share of foreign direct investment inflows by improving business conditions in the formal sector would help reduce external vulnerability (OECD Economic Outlook 2014).

\section{METHODOLOGY}

\subsection{CorrelationAnalysis}

Correlation is a term that refers to the strength of a relationship between two variables. A strong, or high, correlation means that two or more variables have a strong relationship with each other while a weak, or low, correlation means that the variables are hardly related. Correlation coefficients can range from -1.00 to +1.00 . The value of -1.00 represents a perfect negative correlation while a value of +1.00 represents a perfect positive correlation. A value of 0.00 means that there is no relationship between the variables being tested.

The most widely used type of correlation coefficient is the Pearson $r$, which is also referred to as linear or product-moment correlation. This analysis assumes that the two variables being analyzed are measured on at least interval scales. The coefficient is calculated by taking the covariance of the two variables and dividing it by the product of their standard deviations (StatSoft: Electronic Statistics Textbook 2011).

\subsection{Regression analysis}

Regression analysis is a conceptually simple method for investigating functional relationships among variables. A real estate appraiser may wish to relate the sale price of a home from selected physical characteristics of the building and taxes (local, school, county) paid on the building. To examine whether cigarette consumption is related to various socioeconomic and demographic variables such as age, education, income, and price of cigarettes.

The relationship is expressed in the form of an equation or a model connecting the response or dependent variable and one or more explanatory or predictor variables. 
In the cigarette consumption example, the response variable is cigarette consumption (measured by the number of packs of cigarette sold in a given state on a per capita basis during a given year) and the explanatory or predictor variables are the various socioeconomic and demographic variables. In the real estate appraisal example, the response variable is the price of a home and the explanatory or predictor variables are the characteristics of the building and taxes paid on the building (Chatterjee et al. 2006).

\subsection{KrigingMetamodelling}

Krigingmetamodelling technique that can be mathematically expressed as below:

$$
\hat{y}=\hat{\mu}+r^{\prime} R^{-1}(Y-1 \hat{\mu})
$$

In this equation, $\hat{y}$ is the predicted response value of unknown $\mathrm{x}$ (infill sampling point) and $\hat{\mu}$ is the mean of stochastic process. $Y$ is the response value of a design point .The correlation matrix $\mathbf{R}$ gives the correlation between all of design points. The correlation vector $\mathbf{r}$ gives the correlation between infill sampling point and design points.

$$
\begin{aligned}
& R=\exp \left[-\sum_{h=1}^{k} \theta_{h}\left|x_{h}{ }^{(i)}-x^{(j)}\right|^{p_{h}}\right], \quad \theta_{h} \geq 0, \quad p_{h} \in[1,2] \\
& \text { (2) } r_{i}=\exp \left[-\sum_{h=1}^{k} \theta_{h}\left|x_{h}-x_{h}{ }^{(i)}\right|^{2}\right], \theta_{h} \geq 0
\end{aligned}
$$

Maximum Likelihood Estimation is used for predicting $\theta$ parameters. Assuming $Y$ has a normal distribution, likelihood function $(L)$ can be written as follows

$$
L=\frac{1}{(2 \pi)^{\frac{n}{2}}\left(\sigma^{2}\right)^{\frac{n}{2}}|R|^{\frac{1}{2}}} \exp \left[\frac{(y-1 \beta)^{\prime} \mathrm{R}^{-1}(y-1 \beta)}{2 \sigma^{2}}\right]
$$

After obtaining $\theta$ parameters which maximize likelihood function, kriging model must be validated. For this purpose well known Cross-validation method is used for validation. In this method, a prediction is generated with one data point excluded from the data set. Then check whether that data point falls within a certain confidence interval for the prediction. If the test fails, appropriate transformations such as log or inverse may be applied to the response values (Jones, et. al, 1998; Schonlau 1997). 


\section{RESULTS}

In this section, detailed result tables by countries are shown.

\subsection{Results for Brazil}

Table 1:Descriptive statistics for indicators of Brazil

\begin{tabular}{|lc|}
\hline Indicators & Mean \\
GDP Growth Rate (\%) & 3.44624 \\
Total investment (\% of GDP) & 17.88992 \\
Gross national savings (\% of GDP) & 17.08867 \\
Inflation (\%) & 6.5255 \\
Volume of imports of goods and services (\% of & 8.29467 \\
GDP) & \\
Volume of exports of goods and services(\% of & 5.30075 \\
GDP) & 8.67767 \\
Unemployment rate (\%) & 188.07100 \\
Population (Mio) & 35.50233 \\
General government revenue (\% of GDP) & 68.37592 \\
General government gross debt (\% of GDP) & -.80108 \\
Current account balance (\% of GDP) & 36.97592 \\
Real interest rate (\%) & 251.59578 \\
\hline Residential Property Price Index (RPPI) & \\
\hline
\end{tabular}

There are descriptive statistics of Indicators for Brazil on Table 1. Real Interest Rate Average seems so high for time interval from 2002 to 2013. For the same time interval, average GDP growth rate seems not high. Another important average values from the table for General government gross debt. It is 0.68 of GDP for the same time interval.

Referring to Table 2, there are statistically significant, strong relationship between real interest rate, current account balance, general government revenue, population and unemployment rate with RPPI. There are negative relationship between current account balance, unemployment rate, and real interest rate with RPPI. When current account balance, unemployment rate, real interest rate increase, RPPI decreases. There are positive relationship between populations, general government revenue with RPPI. When population and general government revenue increase, RPPI increases. 


\section{Table 2: Correlation matrix for indicators of Brazil}

\begin{tabular}{|c|c|c|c|c|c|c|c|c|c|c|c|c|c|}
\hline & $\begin{array}{c}\text { GDP } \\
\text { Growth } \\
\text { Rate (\%) }\end{array}$ & $\begin{array}{c}\text { Total } \\
\text { investment } \\
\text { (\% of GDP) }\end{array}$ & $\begin{array}{c}\text { Gross } \\
\text { national } \\
\text { savings(\% } \\
\text { of GDP) }\end{array}$ & $\begin{array}{c}\text { Inflation } \\
\text { (\%; Y-o- } \\
\text { Y) }\end{array}$ & 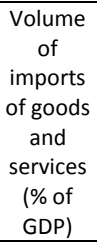 & $\begin{array}{c}\begin{array}{c}\text { Volume } \\
\text { of }\end{array} \\
\text { exports } \\
\text { of goods } \\
\text { and } \\
\text { services } \\
\text { (\% of } \\
\text { GDP) }\end{array}$ & $\begin{array}{l}\text { Unemp. } \\
\text { rate }(\%)\end{array}$ & Populat. & $\begin{array}{c}\text { General } \\
\text { governm } \\
\text { ent } \\
\text { revenue } \\
\text { (\% of } \\
\text { GDP) }\end{array}$ & $\begin{array}{l}\text { General } \\
\text { governm } \\
\text { ent } \\
\text { gross } \\
\text { debt (\% } \\
\text { of GDP) }\end{array}$ & $\begin{array}{c}\text { Current } \\
\text { account } \\
\text { balance } \\
\text { (\% of } \\
\text { GDP) }\end{array}$ & $\begin{array}{c}\text { Real } \\
\text { interest } \\
\text { rate (\%) }\end{array}$ & $\begin{array}{c}\text { Residential } \\
\text { Property } \\
\text { Price Index } \\
\text { (RPPI) }\end{array}$ \\
\hline GDP (\%) & 1 & .463 & $.685(*)$ & -.373 & $.921\left(^{* *}\right)$ & .412 & .052 & -.056 & .078 & -.328 & .182 & -.041 & -.181 \\
\hline Total investment(\% of GDP) & .463 & 1 & .371 & -.485 & .560 & -.397 & $-.678(*)$ & $.664(*)$ & $.715(* *)$ & $\begin{array}{c}- \\
.775(* *) \\
\end{array}$ & $-.579(*)$ & $-.610(*)$ & .531 \\
\hline $\begin{array}{l}\text { Gross national savings(\% of } \\
\text { GDP) }\end{array}$ & $.685\left(^{*}\right)$ & .371 & 1 & -.271 & $.674\left(^{*}\right)$ & .204 & .201 & -.143 & -.250 & -.482 & .543 & .265 & -.390 \\
\hline Inflation(\%; Y-o-Y) & -.373 & -.485 & -.271 & 1 & -.390 & .517 & .516 & -.529 & -.401 & $.665(*)$ & .201 & .462 & -.332 \\
\hline $\begin{array}{l}\text { Volume of imports of goods } \\
\text { and services(\% of GDP) }\end{array}$ & $.921(* *)$ & .560 & $.674\left(^{*}\right)$ & -.390 & 1 & .324 & -.190 & .219 & .251 & -.558 & .085 & -.265 & .079 \\
\hline $\begin{array}{l}\text { Volume of exports of goods } \\
\text { and services(\% of GDP) }\end{array}$ & .412 & -.397 & .204 & .517 & .324 & 1 & $.589\left(^{*}\right)$ & $-.597(*)$ & -.495 & .497 & .538 & .455 & -.464 \\
\hline Unemployment rate (\%) & .052 & $-.678\left(^{*}\right)$ & .201 & .516 & -.190 & $.589(*)$ & 1 & $-.980(* *)$ & $-.908(* *)$ & $.706(*)$ & $.789(* *)$ & $.896(* *)$ & $-.954(* *)$ \\
\hline Population & -.056 & $.664(*)$ & -.143 & -.529 & .219 & $-.597(*)$ & $\begin{array}{c}- \\
\left..980^{* *}\right)\end{array}$ & 1 & $.851(* *)$ & $\begin{array}{c}- \\
.772(* *)\end{array}$ & $-.726(* *)$ & $\begin{array}{c}- \\
.923(* *)\end{array}$ & $.944(* *)$ \\
\hline $\begin{array}{l}\text { General government } \\
\text { revenue(\% of GDP) }\end{array}$ & .078 & $.715(* *)$ & -.250 & -.401 & .251 & -.495 & $\begin{array}{c}- \\
.908(* *)\end{array}$ & $.851(* *)$ & 1 & -.561 & $-.866(* *)$ & $\begin{array}{c}- \\
.829(* *)\end{array}$ & $.859(* *)$ \\
\hline $\begin{array}{l}\text { General government gross } \\
\text { debt( } \% \text { of GDP) }\end{array}$ & -.328 & $-.775(* *)$ & -.482 & $.665\left(^{*}\right)$ & -.558 & .497 & $.706\left(^{*}\right)$ & $-.772(* *)$ & -.561 & 1 & .278 & $.641\left(^{*}\right)$ & -.537 \\
\hline $\begin{array}{l}\text { Current account balance(\% } \\
\text { of GDP) }\end{array}$ & .182 & $-.579\left(^{*}\right)$ & .543 & .201 & .085 & .538 & $.789(* *)$ & $-.726(* *)$ & $-.866(* *)$ & .278 & 1 & $.784\left(^{* *}\right)$ & $-.822(* *)$ \\
\hline Real interest rate (\%) & -.041 & $-.610(*)$ & .265 & .462 & -.265 & .455 & $.896(* *)$ & $-.923(* *)$ & $-.829(* *)$ & $.641(*)$ & $.784\left({ }^{* *}\right)$ & 1 & $-.912(* *)$ \\
\hline $\begin{array}{l}\text { Residential Property Price } \\
\text { Index (RPPI) }\end{array}$ & -.181 & .531 & -.390 & -.332 & .079 & -.464 & $\begin{array}{c}- \\
.954(* *)\end{array}$ & $.944\left(^{* *}\right)$ & $.859(* *)$ & -.537 & $-.822(* *)$ & $\begin{array}{c}- \\
.912(* *)\end{array}$ & 1 \\
\hline
\end{tabular}

* Correlation is significant at the 0.05 level (2-tailed).

** Correlation is significant at the 0.01 level (2-tailed) 
Table 3: Regression model summary

\begin{tabular}{|cccc|}
\hline $\mathrm{R}$ & R Square & $\begin{array}{c}\text { Adjusted R } \\
\text { Square }\end{array}$ & $\begin{array}{c}\text { Std. Error of } \\
\text { the Estimate }\end{array}$ \\
\hline $.992(\mathrm{~b})$ & .985 & .982 & .07733 \\
\hline
\end{tabular}

a Predictors: (Constant), Population

b Predictors: (Constant), Population, Current account balance

c Dependent Variable: InRPPI

Table 4: ANOVA Table for Regression Model

\begin{tabular}{|lccccc|}
\hline & $\begin{array}{c}\text { Sum of } \\
\text { Squares }\end{array}$ & $\mathrm{df}$ & Mean Square & $\mathrm{F}$ & Sig. \\
\hline Regression & 3.518 & 2 & 1.759 & 294.192 & $.000(\mathrm{~b})$ \\
\hline Residual & .054 & 9 & .006 & & \\
\hline Total & 3.572 & 11 & & & \\
\hline
\end{tabular}

a Predictors: (Constant), Population

b Predictors: (Constant), Population, Current account balance

c Dependent Variable: InRPPI

Table 5: Coefficients for Regression Model

\begin{tabular}{|lcccc|}
\hline & $\mathrm{b}_{\mathrm{i}}$ & Std. Error & $\mathrm{t}$ & Sig. \\
\hline (Constant) & -7.456 & .877 & -8.497 & .000 \\
\hline Population & .068 & .005 & 14.404 & .000 \\
\hline Current account balance & -.056 & .019 & -2.975 & .016 \\
\hline
\end{tabular}

a Dependent Variable: InRPPI

According to the Table 3, 4 and 5, there is a statistically significant stepwise regression model with $0.982 \mathrm{R}_{\text {adj. }}^{2}$ Population and current account balance variables explain InRPPI well.

The model can be written as follows;

$$
\operatorname{InRPPI}=-7.456+0.068 * \text { Population-0.056*CurrentAccountBalance }
$$

When current account balance increases, RPPI decreases and when population increases, RPPI increases. Population variable explains RPPI variable better than current account balance variable.

When current account balance increases one percent of GDP, RPPI decreases nearly 5.5\%. When population increases one million, RPPI increases nearly $7 \%$. 
For researching effects of all economic indicators, kriging model was created. When GDP, total investment, gross national savings, volume of imports of goods and services, population, general government revenue increase and inflation, current account balance, unemployment rate, Volume of exports of goods and services, General government gross debt decrease 5\%; RPPI is estimated as 486.5896 . RPPI decreases nearly $2.86 \%$.

\subsection{Results for Indonesia}

There are descriptive statistics of Indicators for Indonesia on Table 6. General government gross debt seems so high for time interval from 2002 to 2013.

Table 6: Descriptive Statistics for Indicators of Indonesia

\begin{tabular}{|lc|}
\hline Indicators & Mean \\
\hline GDP Growth Rate (\%) & 5.60385168755854 \\
\hline Total investment (\% of GDP) & 28.23858 \\
\hline Gross national savings (\% of GDP) & 29.16525 \\
\hline Inflation (\%) & 7.5452 \\
\hline $\begin{array}{l}\text { Volume of imports of goods and services (\% of } \\
\text { GDP) }\end{array}$ & 8.37933 \\
\hline $\begin{array}{l}\text { Volume of exports of goods and services(\% of } \\
\text { GDP) }\end{array}$ & 1.88142 \\
\hline Unemployment rate (\%) & 8.4500 \\
\hline Population (Mio) & 229.6501 \\
\hline General government revenue (\% of GDP) & 18.58817 \\
\hline General government gross debt (\% of GDP) & 38.91750 \\
\hline Current account balance (\% of GDP) & 0.92650 \\
\hline Real interest rate (\%) & 4.72330613293245 \\
\hline Residential Property Price Index (RPPI) & 128.50 \\
\hline
\end{tabular}

Referring to Table 10, there are statistically significant, relationship between, Total Investment, Unemployment rate, population, general government gross debt, current account balance with RPPI. While there are negative relationship between current account balance, unemployment rate, general government gross debt with RPPI, there are positive relationship between, total investments, population with RPPI.

Table 7: Regression Model Summary

\begin{tabular}{|c|c|c|c|}
\hline $\mathrm{R}$ & R Square & $\begin{array}{c}\text { Adjusted R } \\
\text { Square }\end{array}$ & $\begin{array}{c}\text { Std. Error of } \\
\text { the Estimate }\end{array}$ \\
\hline $.984(\mathrm{a})$ & .969 & .965 & .02535 \\
\hline
\end{tabular}

a Predictors: (Constant), Population

b Dependent Variable: InRPPI 
Table 8: ANOVA Table for Regression Model

\begin{tabular}{|lccccc|}
\hline & $\begin{array}{c}\text { Sum of } \\
\text { Squares }\end{array}$ & $\mathrm{df}$ & Mean Square & $\mathrm{F}$ & Sig. \\
\hline Regression & .198 & 1 & .198 & 307.745 & $.000(\mathrm{a})$ \\
\hline Residual & .006 & 10 & .001 & & \\
\hline Total & .204 & 11 & & & \\
\hline
\end{tabular}

a Predictors: (Constant), Population

b Dependent Variable: InRPPI

Table 9: Coefficients for Regression Model

\begin{tabular}{|lcccc|}
\hline & $\mathrm{b}_{\mathrm{i}}$ & Std. Error & $\mathrm{t}$ & Sig. \\
\hline (Constant) & 2.221 & .150 & 14.812 & .000 \\
\hline Population & .011 & .001 & 17.543 & .000 \\
\hline
\end{tabular}

a Dependent Variable: LnRPP 
Table 10:Correlation Matrix for Indicators of Indonesia

\begin{tabular}{|c|c|c|c|c|c|c|c|c|c|c|c|c|c|}
\hline & $\begin{array}{c}\text { GDP } \\
\text { Growth } \\
\text { Rate (\%) }\end{array}$ & $\begin{array}{c}\text { Total } \\
\text { investme } \\
\text { nt(\% of } \\
\text { GDP) }\end{array}$ & $\begin{array}{c}\text { Gross } \\
\text { national } \\
\text { savings } \\
\text { (\% of } \\
\text { GDP) }\end{array}$ & $\begin{array}{l}\text { Inflation } \\
\text { (\%; Y-o- } \\
\text { Y) }\end{array}$ & $\begin{array}{l}\text { Volume of } \\
\text { imports of } \\
\text { goods and } \\
\text { services } \\
\text { (\% of GDP) }\end{array}$ & $\begin{array}{l}\text { Volume of } \\
\text { exports of } \\
\text { goods and } \\
\text { services } \\
\text { (\% of GDP) }\end{array}$ & $\begin{array}{l}\text { Unemploy } \\
\text { m. rate (\%) }\end{array}$ & Populat. & $\begin{array}{l}\text { General } \\
\text { governm } \\
\text { ent } \\
\text { revenue } \\
\text { (\% of } \\
\text { GDP) } \\
\end{array}$ & $\begin{array}{c}\text { General } \\
\text { governm } \\
\text { ent gross } \\
\text { debt (\% } \\
\text { of GDP) }\end{array}$ & $\begin{array}{c}\text { Current } \\
\text { account } \\
\text { balance } \\
\text { (\% of } \\
\text { GDP) }\end{array}$ & $\begin{array}{c}\text { Real } \\
\text { interest } \\
\text { rate (\%) }\end{array}$ & $\begin{array}{c}\text { Resident } \\
\text { ial } \\
\text { Property } \\
\text { Price } \\
\text { Index } \\
\text { (RPPI) } \\
\end{array}$ \\
\hline GDP (\%) & 1 & 0.539 & 0.319 & -0.293 & 0.567 & 0.157 & -0.432 & $.657\left(^{*}\right)$ & 0.186 & $-.729(* *)$ & $-.645\left(^{*}\right)$ & -0.537 & $.607\left(^{*}\right)$ \\
\hline $\begin{array}{l}\text { Total investment (\% } \\
\text { of GDP) }\end{array}$ & 0.539 & 1 & $.892(* *)$ & $-.688(*)$ & 0.098 & 0.343 & $-.875(* *)$ & $.950(* *)$ & -0.469 & $-.868(* *)$ & $-.790(* *)$ & -0.032 & $.895(* *)$ \\
\hline $\begin{array}{l}\text { Gross national } \\
\text { savings (\% of GDP) }\end{array}$ & 0.319 & $.892(* *)$ & 1 & $-.683(*)$ & -0.053 & 0.399 & $-.794(* *)$ & $.763(* *)$ & $-.638(*)$ & $-.739(* *)$ & -0.427 & 0.122 & $.657(*)$ \\
\hline Inflation (\%; Y-o-Y) & -0.293 & $-.688\left(^{*}\right)$ & $-.683(*)$ & 1 & -0.103 & 0.062 & $.673(*)$ & $-.583\left(^{*}\right)$ & $.601(*)$ & 0.502 & 0.45 & -0.229 & -0.503 \\
\hline $\begin{array}{l}\text { Volume of imports of } \\
\text { goods and services } \\
\text { (\% of GDP) }\end{array}$ & 0.567 & 0.098 & -0.053 & -0.103 & 1 & 0.17 & -0.005 & 0.089 & 0.241 & -0.136 & -0.268 & -0.464 & 0.01 \\
\hline $\begin{array}{l}\text { Volume of exports of } \\
\text { goods and services } \\
\text { (\% of GDP) }\end{array}$ & 0.157 & 0.343 & 0.399 & 0.062 & 0.17 & 1 & -0.057 & 0.295 & -0.357 & -0.387 & -0.145 & -0.234 & 0.237 \\
\hline $\begin{array}{l}\text { Unemployment rate } \\
\text { (\%) }\end{array}$ & -0.432 & $-.875(* *)$ & $-.794(* *)$ & $.673(*)$ & -0.005 & -0.057 & 1 & $-.855(* *)$ & 0.537 & $.697(*)$ & $.672(*)$ & -0.224 & $-.809(* *)$ \\
\hline Population & $.657\left(^{*}\right)$ & $.950(* *)$ & $.763(* *)$ & $-.583(*)$ & 0.089 & 0.295 & $-.855(* *)$ & 1 & -0.325 & $-.937(* *)$ & $-.864(* *)$ & -0.179 & $.974(* *)$ \\
\hline $\begin{array}{l}\text { General government } \\
\text { revenue ( } \% \text { of GDP) }\end{array}$ & 0.186 & -0.469 & $-.638\left(^{*}\right)$ & $.601\left(^{*}\right)$ & 0.241 & -0.357 & 0.537 & -0.325 & 1 & 0.192 & 0.072 & $-.664(*)$ & -0.267 \\
\hline $\begin{array}{l}\text { General government } \\
\text { gross debt }(\% \text { of } \\
\text { GDP })\end{array}$ & $-.729(* *)$ & $-.868(* *)$ & $-.739(* *)$ & 0.502 & -0.136 & -0.387 & $.697\left(^{*}\right)$ & $-.937(* *)$ & 0.192 & 1 & $.734(* *)$ & 0.421 & $-.871(* *)$ \\
\hline $\begin{array}{l}\text { Current account } \\
\text { balance (\% of GDP) }\end{array}$ & $-.645(*)$ & $-.790(* *)$ & -0.427 & 0.45 & -0.268 & -0.145 & $.672\left(^{*}\right)$ & $-.864(* *)$ & 0.072 & $.734(* *)$ & 1 & 0.231 & $-.899(* *)$ \\
\hline Real interest rate (\%) & -0.537 & -0.032 & 0.122 & -0.229 & -0.464 & -0.234 & -0.224 & -0.179 & $-.664(*)$ & 0.421 & 0.231 & 1 & -0.143 \\
\hline $\begin{array}{l}\text { Residential Property } \\
\text { Price Index (RPPI) }\end{array}$ & $.607(*)$ & $.895(* *)$ & $.657(*)$ & -0.503 & 0.01 & 0.237 & $-.809(* *)$ & $.974(* *)$ & -0.267 & $-.871(* *)$ & $-.899(* *)$ & -0.143 & 1 \\
\hline
\end{tabular}

* Correlation is significant at the 0.05 level (2-tailed).

** Correlation is significant at the 0.01 level (2-taile 
According to the Table 7, 8 and 9, there is a statistically significant stepwise regression model with $0.965 \mathrm{R}^{2}$ adj. Population explains InRPPI well.

The model can be written as follows;

$\operatorname{lnRPPI}=2.221+0.011 *$ Population

When population increases, RPPI increases. When population increases one million, RPPI increases nearly $1 \%$.

For researching effects of all economic indicators, kriging model was created. When GDP, total investment, gross national savings, volume of imports of goods and services, population, General government revenue increase and inflation, current account balance, unemployment rate, Volume of exports of goods and services, General government gross debt decrease 5\%; RPPI is estimated as 164.4999 . RPPI decreases nearly $0.09 \%$.

\subsection{Results for South Africa}

Table 11: Descriptive Statistics for Indicators of South Africa

\begin{tabular}{|lc|}
\hline Indicators & Mean \\
\hline GDP Growth Rate (\%) & 1.984981796 \\
\hline Total investment (\% of GDP) & 19.05316667 \\
\hline Gross national savings (\% of GDP) & 15.26108333 \\
\hline Inflation (\%) & 5.907 \\
\hline $\begin{array}{l}\text { Volume of imports of goods and services (\% of } \\
\text { GDP) }\end{array}$ & 6.905666667 \\
\hline $\begin{array}{l}\text { Volume of exports of goods and services(\% of } \\
\text { GDP) }\end{array}$ & 2.426333333 \\
\hline Unemployment rate (\%) & 24.93475 \\
\hline Population (Mio) & 49.2605 \\
\hline General government revenue (\% of GDP) & 27.5035 \\
\hline General government gross debt (\% of GDP) & 35.209 \\
\hline Current account balance (\% of GDP) & -9.02041667 \\
\hline Real interest rate (\%) & 4.440973394 \\
\hline Residential Property Price Index (RPPI) & 308.4777778 \\
\hline
\end{tabular}

There are descriptive statistics of Indicators for South Africa on Table 11. General government gross debt seems so high for time interval from 2002 to 2013 . For the same time interval, average GDP growth rate seems not high.

Referring to Table 12, there are statistically significant, relationship between, total Investment, population, general government revenue, unemployment rate and real interest rate with RPPI. 
Table 12. Correlation Matrix for Indicators of South Africa

\begin{tabular}{|c|c|c|c|c|c|c|c|c|c|c|c|c|c|}
\hline & $\begin{array}{c}\text { GDP } \\
\text { Growth } \\
\text { Rate (\%) }\end{array}$ & $\begin{array}{c}\text { Total } \\
\text { investment } \\
\text { (\% of GDP) }\end{array}$ & $\begin{array}{c}\text { Gross } \\
\text { national } \\
\text { savings } \\
\text { (\% of } \\
\text { GDP) }\end{array}$ & $\begin{array}{l}\text { Inflation } \\
(\% ; Y-0-Y)\end{array}$ & $\begin{array}{l}\text { Volume } \\
\text { of } \\
\text { imports } \\
\text { of goods } \\
\text { and } \\
\text { services } \\
\text { (\% of } \\
\text { GDP) } \\
\end{array}$ & 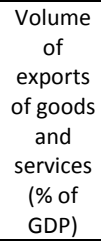 & $\begin{array}{l}\text { Unemploy. } \\
\text { rate (\%) }\end{array}$ & Populat. & $\begin{array}{c}\text { General } \\
\text { governm } \\
\text { ent } \\
\text { revenue } \\
\text { (\% of } \\
\text { GDP) }\end{array}$ & $\begin{array}{c}\text { General } \\
\text { governm } \\
\text { ent gross } \\
\text { debt (\% } \\
\text { of GDP) }\end{array}$ & $\begin{array}{c}\text { Current } \\
\text { account } \\
\text { balance } \\
\text { (\% of } \\
\text { GDP) }\end{array}$ & $\begin{array}{c}\text { Real } \\
\text { interest } \\
\text { rate (\%) }\end{array}$ & $\begin{array}{l}\text { Residenti } \\
\text { al } \\
\text { Property } \\
\text { Price } \\
\text { Index } \\
\text { (RPPI) }\end{array}$ \\
\hline GDP (\%) & 1 & 0.073 & -0.169 & -0.271 & $.878\left({ }^{* *}\right)$ & $.849(* *)$ & -0.056 & -0.366 & 0.015 & -0.292 & -0.35 & 0.256 & -0.24 \\
\hline $\begin{array}{l}\text { Total investment (\% of } \\
\text { GDP) }\end{array}$ & 0.073 & 1 & -0.3 & 0.37 & -0.172 & 0.015 & $-.939(* *)$ & 0.525 & $.914\left({ }^{* *}\right)$ & -0.474 & -0.467 & -0.125 & $.715\left({ }^{* *}\right)$ \\
\hline $\begin{array}{l}\text { Gross national savings (\% } \\
\text { of GDP) }\end{array}$ & -0.169 & -0.3 & 1 & 0.164 & -0.081 & -0.042 & 0.348 & -0.212 & -0.411 & -0.105 & 0.344 & -0.059 & -0.244 \\
\hline Inflation (\%; Y-o-Y) & -0.271 & 0.37 & 0.164 & 1 & -0.516 & -0.306 & -0.158 & 0 & 0.31 & -0.332 & -0.158 & 0.262 & 0.052 \\
\hline $\begin{array}{l}\text { Volume of imports of } \\
\text { goods and services (\% of } \\
\text { GDP) }\end{array}$ & $.878(* *)$ & -0.172 & -0.081 & -0.516 & 1 & $.892(* *)$ & 0.182 & -0.244 & -0.169 & 0.094 & -0.058 & 0.107 & -0.226 \\
\hline $\begin{array}{l}\text { Volume of exports of goods } \\
\text { and services (\% of GDP) }\end{array}$ & $.849\left({ }^{* *}\right)$ & 0.015 & -0.042 & -0.306 & $.892\left({ }^{* *}\right)$ & 1 & 0.028 & -0.024 & 0.051 & 0.083 & -0.164 & -0.022 & 0.02 \\
\hline Unemployment rate (\%) & -0.056 & $-.939(* *)$ & 0.348 & -0.158 & 0.182 & 0.028 & 1 & -0.538 & $-.902(* *)$ & 0.485 & 0.406 & 0.314 & $-.742(* *)$ \\
\hline Population & -0.366 & 0.525 & -0.212 & 0 & -0.244 & -0.024 & -0.538 & 1 & $.687(*)$ & 0.406 & -0.02 & $-.634\left(^{*}\right)$ & $.957(* *)$ \\
\hline $\begin{array}{l}\text { General government } \\
\text { revenue (\% of GDP) }\end{array}$ & 0.015 & $.914(* *)$ & -0.411 & 0.31 & -0.169 & 0.051 & $-.902(* *)$ & $.687\left({ }^{*}\right)$ & 1 & -0.27 & -0.475 & -0.349 & $.842(* *)$ \\
\hline $\begin{array}{l}\text { General government gross } \\
\text { debt (\% of GDP) }\end{array}$ & -0.292 & -0.474 & -0.105 & -0.332 & 0.094 & 0.083 & 0.485 & 0.406 & -0.27 & 1 & 0.421 & -0.309 & 0.14 \\
\hline $\begin{array}{l}\text { Current account balance (\% } \\
\text { of GDP) }\end{array}$ & -0.35 & -0.467 & 0.344 & -0.158 & -0.058 & -0.164 & 0.406 & -0.02 & -0.475 & 0.421 & 1 & -0.034 & -0.186 \\
\hline Real interest rate (\%) & 0.256 & -0.125 & -0.059 & 0.262 & 0.107 & -0.022 & 0.314 & $-.634\left({ }^{*}\right)$ & -0.349 & -0.309 & -0.034 & 1 & $-.611(*)$ \\
\hline $\begin{array}{l}\text { Residential Property Price } \\
\text { Index (RPPI) }\end{array}$ & -0.24 & $.715(* *)$ & -0.244 & 0.052 & -0.226 & 0.02 & $-.742(* *)$ & $.957(* *)$ & $.842(* *)$ & 0.14 & -0.186 & $-.611(*)$ & 1 \\
\hline
\end{tabular}

* Correlation is significant at the 0.05 level (2-tailed).
$*$
Correlation
is
significant
at
the
0.01
level
(2-tailed 
Table 13: Regression Model Summary

\begin{tabular}{|cccc|}
\hline R & R Square & $\begin{array}{c}\text { Adjusted R } \\
\text { Square }\end{array}$ & $\begin{array}{c}\text { Std. Error of } \\
\text { the Estimate }\end{array}$ \\
\hline $.991(\mathrm{a})$ & .981 & .977 & .05795 \\
\hline
\end{tabular}

a Predictors: (Constant), Population, Unemployment rate

b Dependent Variable: InRPPI

Table 14: ANOVA Table for Regression Model

\begin{tabular}{|lccccc|}
\hline & $\begin{array}{c}\text { Sum of } \\
\text { Squares }\end{array}$ & df & Mean Square & $F$ & Sig. \\
\hline Regression & 1.575 & 2 & .787 & 234.444 & .000 (a) \\
\hline Residual & .030 & 9 & .003 & & \\
\hline Total & 1.605 & 11 & & & \\
\hline
\end{tabular}

a Predictors: (Constant), Population, Unemployment rate

b Dependent Variable: InRPPI

Table 15: Coefficients for Regression Model

\begin{tabular}{|lcccc|}
\hline & $\mathrm{b}_{\mathrm{i}}$ & Std. Error & $\mathrm{t}$ & Sig. \\
\hline (Constant) & 2.873 & .643 & 4.470 & .002 \\
\hline Population & .108 & .009 & 12.502 & .000 \\
\hline Unemployment rate & -.100 & .012 & -8.183 & .000 \\
\hline
\end{tabular}

a Dependent Variable: InRPPI

According to the Table 13, 14 and 15, there is a statistically significant stepwise regression model with $0.977 \mathrm{R}^{2}$ adj. Population and unemployment rate variables explain InRPPI well.

The model can be written as follows;

InRPPI $=2.873+0.108 *$ Population-0.1*Unemployment rate

When unemployment rate increases, RPPI decreases and when population increases, RPPI increases. Population variable explains RPPI variable better than unemployment rate variable.

When unemployment rate increases one percent, RPPI decreases nearly $10.5 \%$. When population increases one unit, RPPI increases nearly $11.4 \%$.

For researching effects of all economic indicators, kriging model was created. When GDP, total investment, gross national savings, volume of imports of goods and services, population, general government revenue increase and inflation, current account balance, unemployment rate, Volume of exports of goods and services, General government gross debt decrease 5\%; RPPI is estimated as 399.0367. RPPI decreases nearly $7.09 \%$. 
Table 16:CorrelationMatrixforIndicators of Turkey

\begin{tabular}{|c|c|c|c|c|c|c|c|c|c|c|c|c|c|}
\hline & $\begin{array}{c}\text { GDP } \\
\text { Growth } \\
\text { Rate (\%) }\end{array}$ & $\begin{array}{c}\text { Total } \\
\text { investmen } \\
t \text { (\% of } \\
\text { GDP) }\end{array}$ & $\begin{array}{c}\text { Gross } \\
\text { national } \\
\text { savings } \\
\text { (\% of } \\
\text { GDP) }\end{array}$ & $\begin{array}{l}\text { Inflation } \\
\text { (\%; Y-o-Y) }\end{array}$ & $\begin{array}{c}\begin{array}{c}\text { Volume } \\
\text { of }\end{array} \\
\text { imports } \\
\text { of goods } \\
\text { and } \\
\text { services } \\
\text { (\% of } \\
\text { GDP) }\end{array}$ & 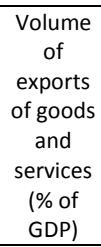 & $\begin{array}{c}\text { Unemplo } \\
\text { y. rate } \\
\text { (\%) }\end{array}$ & Populat. & $\begin{array}{c}\text { General } \\
\text { governm } \\
\text { ent } \\
\text { revenue } \\
\text { (\% of } \\
\text { GDP) }\end{array}$ & $\begin{array}{c}\text { General } \\
\text { governm } \\
\text { ent gross } \\
\text { debt (\% } \\
\text { of GDP) }\end{array}$ & $\begin{array}{c}\text { Current } \\
\text { account } \\
\text { balance } \\
\text { (\% of } \\
\text { GDP) }\end{array}$ & $\begin{array}{c}\text { Real } \\
\text { interest } \\
\text { rate (\%) }\end{array}$ & $\begin{array}{l}\text { Residenti } \\
\text { al } \\
\text { Property } \\
\text { Price } \\
\text { Index } \\
\text { (RPPI) }\end{array}$ \\
\hline GDP (\%) & 1 & 0.463 & 0.273 & 0.087 & $.882(* *)$ & $.638(*)$ & -0.53 & -0.25 & -0.055 & 0.234 & -0.023 & -0.014 & -0.221 \\
\hline $\begin{array}{l}\text { Total investment (\% of } \\
\text { GDP) }\end{array}$ & 0.463 & 1 & 0.091 & -0.392 & 0.181 & 0.181 & $-.667(*)$ & 0.383 & 0.487 & -0.553 & -0.157 & -0.293 & 0.538 \\
\hline $\begin{array}{l}\text { Gross national savings (\% } \\
\text { of GDP) }\end{array}$ & 0.273 & 0.091 & 1 & .609 & 0.377 & 0.464 & -0.349 & $-.771(* *)$ & $-.742\left({ }^{* *}\right)$ & $.604(*)$ & -0.013 & 0.335 & -.583 \\
\hline Inflation (\%; Y-o-Y) & 0.087 & -0.392 & .609 & 1 & 0.374 & 0.206 & -0.123 & -.625 & -.722 & .810 & 0.075 & 0.003 & .725 \\
\hline $\begin{array}{l}\text { Volume of imports of } \\
\text { goods and services (\% of } \\
\text { GDP) }\end{array}$ & $.882(* *)$ & 0.181 & 0.377 & 0.374 & 1 & $.729\left({ }^{* *}\right)$ & -0.486 & -0.454 & -0.322 & 0.498 & -0.226 & 0.152 & -0.403 \\
\hline $\begin{array}{l}\text { Volume of exports of goods } \\
\text { and services (\% of GDP) }\end{array}$ & $.638(*)$ & 0.181 & 0.464 & 0.206 & $.729(* *)$ & 1 & $-.590\left(^{*}\right)$ & -0.494 & -0.353 & 0.392 & -0.241 & 0.423 & -0.347 \\
\hline Unemployment rate (\%) & -0.53 & $-.667\left(^{*}\right)$ & -0.349 & -0.123 & -0.486 & $-.590(*)$ & 1 & -0.054 & -0.177 & 0.044 & 0.178 & 0.107 & -0.211 \\
\hline Population & -0.25 & 0.383 & $-.771(* *)$ & -.625 & -0.454 & -0.494 & -0.054 & 1 & $.923(* *)$ & $-.879\left(^{* *}\right)$ & 0.089 & -.647 & $.899(* *)$ \\
\hline $\begin{array}{l}\text { General government } \\
\text { revenue (\% of GDP) }\end{array}$ & -0.055 & 0.487 & $-.742(* *)$ & -.722 & -0.322 & -0.353 & -0.177 & $.923(* *)$ & 1 & $-.825(* *)$ & 0.107 & -0.511 & $.892(* *)$ \\
\hline $\begin{array}{l}\text { General government gross } \\
\text { debt (\% of GDP) }\end{array}$ & 0.234 & -0.553 & $.604(*)$ & .810 & 0.498 & 0.392 & 0.044 & $-.879(* *)$ & $-.825(* *)$ & 1 & 0.136 & 0.463 & $-.926(* *)$ \\
\hline $\begin{array}{l}\text { Current account balance (\% } \\
\text { of GDP) }\end{array}$ & -0.023 & -0.157 & -0.013 & 0.075 & -0.226 & -0.241 & 0.178 & 0.089 & 0.107 & 0.136 & 1 & -0.264 & -0.148 \\
\hline Real interest rate (\%) & -0.014 & -0.293 & 0.335 & 0.003 & 0.152 & 0.423 & 0.107 & -.647 & -0.511 & 0.463 & -0.264 & 1 & -0.459 \\
\hline $\begin{array}{l}\text { Residential Property Price } \\
\text { Index (RPPI) }\end{array}$ & -0.221 & 0.538 & $-.583(*)$ & $-.725(* *)$ & -0.403 & -0.347 & -0.211 & $.899(* *)$ & $.892(* *)$ & $-.926(* *)$ & -0.148 & -0.459 & 1 \\
\hline
\end{tabular}

* Correlation is significant at the 0.05 level (2-tailed).

** Correlation is significant at the 0.01 level (2-tailed) 


\subsection{Results for Turkey}

Table 17: Descriptive Statistics for Indicators of Turkey

\begin{tabular}{|lc|}
\hline Indicators & Mean \\
\hline GDP Growth Rate (\%) & 3.69883316785921 \\
\hline Total investment (\% of GDP) & 19.92975 \\
\hline Gross national savings (\% of GDP) & 14.92167 \\
\hline Inflation (\%) & 12.81000 \\
\hline $\begin{array}{l}\text { Volume of imports of goods and services (\% of } \\
\text { GDP) }\end{array}$ & 9.53417 \\
\hline $\begin{array}{l}\text { Volume of exports of goods and services(\% of } \\
\text { GDP) }\end{array}$ & 8.45783 \\
\hline Unemployment rate (\%) & 10.64283 \\
\hline Population (Mio) & 70.85392 \\
\hline General government revenue (\% of GDP) & 32.54708 \\
\hline General government gross debt (\% of GDP) & 48.33 \\
\hline Current account balance (\% of GDP) & -11.26067 \\
\hline Real interest rate (\%) & 9.05431904210532 \\
\hline Residential Property Price Index (RPPI) & 90.97893611111110 \\
\hline
\end{tabular}

There are descriptive statistics of Indicators for Turkey on Table 17. General government revenue seems high for time interval from 2002 to 2013.

Referring to Table 16, there are statistically significant, relationship between population, general government revenue, and general government gross debt with RPPI. While there is negative relationship between general government gross debt with RPPI, there are positive relationship between population, general government revenue with RPPI.

Table 18: Regression Model Summary

\begin{tabular}{|cccc|}
\hline R & R Square & $\begin{array}{c}\text { Adjusted R } \\
\text { Square }\end{array}$ & $\begin{array}{c}\text { Std. Error of } \\
\text { the Estimate }\end{array}$ \\
\hline $.971(a)$ & .942 & .930 & .05502 \\
\hline
\end{tabular}

a Predictors: (Constant), General government gross debt, General government revenue

b Dependent Variable: InRPPI

Table 19: ANOVA Table for Regression Model

\begin{tabular}{|lccccc|}
\hline & $\begin{array}{c}\text { Sum of } \\
\text { Squares }\end{array}$ & df & Mean Square & $F$ & Sig. \\
\hline Regression & .446 & 2 & .223 & 73.621 & $.000(\mathrm{a})$ \\
\hline Residual & .027 & 9 & .003 & & \\
\hline Total & .473 & 11 & & & \\
\hline
\end{tabular}

a Predictors: (Constant), General government gross debt, General government revenue

b Dependent Variable: InRPPI 
Table 20: Coefficients for Regression Model

\begin{tabular}{|lccccc|}
\hline & & $\mathrm{b}_{\mathrm{i}}$ & Std. Error & $\mathrm{t}$ & Sig. \\
\hline (Constant) & 3.891 & .593 & 6.561 & .000 \\
\hline $\begin{array}{l}\text { General } \\
\text { gross debt }\end{array}$ & government & -.011 & .002 & -4.825 & .001 \\
\hline $\begin{array}{l}\text { General } \\
\text { revenue }\end{array}$ & government & .035 & .015 & 2.304 & .047 \\
\hline
\end{tabular}

a Dependent Variable: InRPPI

According to the Table 18,19 and 20 , there is a statistically significant stepwise regression model with $0.93 \mathrm{R}^{2}$ adj. General government gross debt and General government revenue variables explain InRPPI well.

The model can be written as follows;

InRPPI $=3.891-0.011 *$ General government gross debt $+0.035 *$ General government revenue

When General government gross debt increases, RPPI decreases and when General government revenue increases, RPPI increases. General government revenue variable explains RPPI variable better than General government gross debt. When General government gross debt increases one percent of GDP, RPPI decreases nearly $1 \%$. When General government revenue increases one unit, RPPI increases nearly 3.6\%.

For researching effects of all economic indicators, kriging model was created. When GDP, total investment, gross national savings, volume of imports of goods and services, population, general government revenue increase and inflation, current account balance, unemployment rate, volume of exports of goods and services, general government gross debt decrease 5\%; RPPI is estimated as 117.5026 . RPPI decreases nearly $6.34 \%$.

\section{CONCLUSION}

For Brazil, there are statistically significant, strong relationship between real interest rate, current account balance, general government revenue, population and unemployment rate with RPPI. There are negative relationship between current account balance, unemployment rate, and real interest rate with RPPI. When current account balance, unemployment rate, real interest rate increase, RPPI decreases. There are positive relationship between populations, general government revenue with RPPI. Population variable explains RPPI variable better than current account balance variable. When current account balance increases one percent of GDP, RPPI decreases nearly $5.5 \%$. When population increases one million, RPPI increases nearly $7 \%$. For researching effects of all economic indicators, kriging model was created. 
When GDP, total investment, gross national savings, volume of imports of goods and services, population, general government revenue increase and inflation, current account balance, unemployment rate, Volume of exports of goods and services, General government gross debt decrease 5\%; RPPI is estimated as 486.5896. RPPI decreases nearly $2.86 \%$.

For Indonesia; there are statistically significant, relationship between, Total Investment, Unemployment rate, population, general government gross debt, current account balance with RPPI. While there are negative relationship between current account balance, unemployment rate, general government gross debt with RPPI, there are positive relationship between, total investments, population with RPPI. When population increases, RPPI increases. When population increases one million, RPPI increases nearly $1 \%$. For researching effects of all economic indicators, kriging model was created. When GDP, total investment, gross national savings, volume of imports of goods and services, population, General government revenue increase and inflation, current account balance, unemployment rate, Volume of exports of goods and services, General government gross debt decrease 5\%; RPPI is estimated as 164.4999 . RPPI decreases nearly $0.09 \%$.

For South Africa; there are statistically significant, relationship between, Total Investment, population, general government revenue with RPPI. While there are negative relationship between unemployment rate and real interest rate with RPPI. When unemployment rate increases, RPPI decreases and when population increases, RPPI increases. Population variable explains RPPI variable better than unemployment rate variable. When unemployment rate increases one percent, RPPI decreases nearly $10.5 \%$. When population increases one unit, RPPI increases nearly $11.4 \%$. For researching effects of all economic indicators, kriging model was created. When GDP, total investment, gross national savings, volume of imports of goods and services, population, general government revenue increase and inflation, current account balance, unemployment rate, Volume of exports of goods and services, General government gross debt decrease 5\%; RPPI is estimated as 399.0367. RPPI decreases nearly $7.09 \%$.

For Turkey; there are statistically significant, relationship between population, general government revenue, and general government gross debt with RPPI. While there is negative relationship between general government gross debt with RPPI, there are positive relationship between population, general government revenue with RPPI.When General government gross debt increases, RPPI decreases and when General government revenue increases, RPPI increases. General government revenue variable explains RPPI variable better than General government gross debt. When General government gross debt increases one percent of GDP, RPPI decreases nearly $1 \%$. When General government revenue increases one unit, RPPI increases nearly 3.6\%. For researching effects of all economic indicators, kriging model was created. When GDP, total investment, gross national savings, volume of imports of goods and services, population, general government revenue increase and inflation, current account balance, unemployment rate, volume of exports of goods and services, general government gross debt decrease $5 \%$; RPPI is estimated as 117.5026 . RPPI decreases nearly $6.34 \%$. 
The paper is the first academic study that investigating, modelling whether there is a longrun relationship between macroeconomic indicators and housing markets in Fragile 5 countries. The findings of this paper would help government and property investors for creating more effective property management strategies in these countries (especially in Brazil and Turkey).On the other hand due to lack of housing market data, statistical models could not be created for India.

\section{ACKNOWLEDGEMENT}

REIDIN (Real Estate Investment and Development Information Networkhttp://www.reidin.com) is the world's first global business information service, that is designed to meet the unique requirements of real estate market professionals who are interested in the emerging countries, develops residential property price indices for number of countries including Turkey. We would like to thank REIDIN as their index plays an essential role on this study.

\section{REFERENCES}

- $\quad$ Amiri, M. P., Amiri, A. P. and Amiri, M. P. (2012). An analytical network processapproachforevaluatingbankingperformancebased on balancedscorecard. Trends in AppliedSciencesResearch, 7(6), 456-466.

- Ashourian, M. (2012). EvaluatingtheRank of Performance of Countries of theMiddle East and North Africawith MADM. Journal of Informaticsand Mathematical Sciences, 4(3).

- $\quad$ Carree, M. A. \&Turik, A. R. (2008). Thelagstructure of theimpact of businessownership on economicperformance in OECD countries. Small Business Economics, 30, 101-110.

- $\quad$ Chen, S. J.,Hwang, C. L. (1992). Fuzzymultipleattributedecisionmaking: Methodsandapplications. Berlin: Springer- Verlag.

- $\quad$ Chen, Y. S., Lin, C. T. and Lu, J. H. (2010). Theanalytic network processforthebankingsector: An approachtoevaluatethecreditability of emergingindustries. AfricanJournal of Business Management, 5(4), 1343-1352.

- Emara, N. (2014). Quantitative Evaluation of theStruggle of EconomicPerformance: The Case of MENA Countries. Topics in MiddleEasternandAfricanEconomies, 16(2), 184-191.

- Hernández, C. T., Castro, R. C., Marins, F. A. S., Duran, J. A. R., (2012). “Using theAnalytic Network Process to Evaluate the Relation between Reverse Logistics and Corporate Performance in Brazilian Companies", Revista Investigación Operacional, Vol: 33, No: 1, 13-22 
- Hwang, C.L.,Yoon, K. (1981). Multiple attribute decision making: Method and application. New York: Spring-Verlag.

- International Monetary Fund (IMF), (2013). IMF, Brazil Country Report, No: $13 / 312$.

- International Monetary Fund (IMF), (2013). IMF, India Country Report, No: 14/57.

- International Monetary Fund (IMF), (2013). IMF, Indonesia Country Report, No: $13 / 362$.

- International MonetaryFund (IMF), (2013). IMF, South Africa Country Report, No: $13 / 303$.

- International MonetaryFund (IMF), (2014), IMF World Economic Outlook Database,(Availableonline at http://www.imf.org/external/pubs/ft/weo/2014/01/weodata/index.aspx)

- Ishizaka, A.,Nemery, P., (2013). Multi-CriteriaDecision Analysis: Methods and Software. John Wiley\&Sons, Ltd, United Kingdom.

- Lai, Y.J.,Liu, T.Y. and Hwang, C.L. (1994). TOPSIS for MODM. European Journal of Operational Research, 76, 486-500.

- Morgan Stanley, (2013). FX Pulse Preparing for Volatility, Morgan Stanley Research Paper, http://www.morganstanleyfa.com/public/projectfiles/dce4d168-15f9-42459605-e37e2caf114c.pdf Accesed 5 June 2014

- Niemira, M. P. \&Saaty, T. L. (2004). An Analytic Network Process model for financial-crisis forecasting. International Journal of Forecasting, 20, 573-587.

- Öztürk, S.,Sözdemir, A. and Ülger, Ö. (2014). The Effects of Inflation Targeting Strategy on the Growing Performance of Developed and Developing Countries: Evaluation of Preand Post Stages of Global Financial Crisis. Procedia - Social and Behavioral Sciences, 109. 57-64.

- $\quad$ Reidin.com, (2014). Real Estate Investment and Development Information Network, http://www.reidin.com Accessed 1 October 2014).

- $\quad$ Saaty, T. L., (2008). Decision Making With the Analytic Hierarchy Process. Int. J. Services Sciences, 1 (1) 
- Saaty, T. L.,Vargas L. G.., (2001). Models, Methods, Concepts \& Applications of the Analytic Hierarchy Process. International Series in Operations Research\& Management Science, KluwerAcademic Publishers.

- Saaty, T.L., (1980). The analytic hierarchy process. New York: McGraw-Hill.

- Saaty, T.L., (1990). How to Make Decision: The Analytic Hierarchy Process, European Journal of Operational Research, North Holland, 48, 9-26.

- Saljoughian, M. et al. (2013). Performance Evaluation of OECD Countries by Data Envelopment analysis based on Science and Technology Factors. Journal of Applied Science and Engineering Management, 1(1), 24-35.

- The Organisation for Economic Co-operationand Development (OECD), (2014). Economic Outlook, No: 1.

- Tzeng, G.H. and Huang, J.J. (2011). “Multi AttributeDecision Making: Methods and Applications", CRC Press, ISBN: 978-1-4398-6157-8, USA.

- Ghysels, E. et al (2012) Forecasting Real EstatePrices, Handbook of Economic Forecasting: Vol II, G. Elliottand A. Timmermann (Eds.), Elsevier, forthcoming.

- Seth, J (2011) Forecasting The Real Estate Market: A Cointegrated Approach Master Of Arts Thesis, The Faculty of the Department of Economics University of Houston.

- Guo J. (2012) Housing Price Forecasting based on Stochastic Time Series Model, Int.J.Buss.Mgt.Eco.Res.,Vol 3(2), 2012, 498-505

- Box, G. E. P., G. M. Jenkins, and G. C. Reinsel (1994). Time Series Analysis: Forecasting and Control 3rd ed. Englewood Cliffs, NJ: Prentice Hall.

- D. R. Jones, M. Schonlau, and W. J. Welch (1998), Efficient Global Optimization of Expensive Black-Box Functions, Journal of Global Optimization, 13, 455-492

- M. Schonlau(1997), ComputerExperiments and Global Optimization, Phd. Thesis, University of Waterloo.

- StatSoft: Electronic Statistics Textbook. (2011).

- $\quad$ Chatterjee, S. and Hadi, A.,S., (2006), Regression Analysis by Example Fourth Edition, John Wiley\&Sons, Inc, p.1. 